\title{
Exploring the Relationship between Writing Anxiety and the Pedagogical Use of Online Learning Medium among Malaysian University Students
}

Siti Faridah Kamaruddin, Imelia Laura Daneil, Tang Howe Eng

To Link this Article: http://dx.doi.org/10.6007/IJARBSS/v11-i4/9842 DOI:10.6007/IJARBSS/v11-i4/9842

Received: 09 February 2021, Revised: 10 March 2021, Accepted: 29 March 2021

Published Online: 25 April 2021

In-Text Citation: (Kamaruddin et al., 2021)

To Cite this Article: Kamaruddin, S. F., Daneil, I. L., \& Eng, T. H. (2021). Exploring the Relationship between Writing Anxiety and the Pedagogical Use of Online Learning Medium among Malaysian University Students. International Journal of Academic Research in Business and Social Sciences, 11(4), 1450-1468.

Copyright: (C) 2021 The Author(s)

Published by Human Resource Management Academic Research Society (www.hrmars.com)

This article is published under the Creative Commons Attribution (CC BY 4.0) license. Anyone may reproduce, distribute, translate and create derivative works of this article (for both commercial and non-commercial purposes), subject to full attribution to the original publication and authors. The full terms of this license may be seen at: http://creativecommons.org/licences/by/4.0/legalcode

Vol. 11, No. 4, 2021, Pg. 1450 - 1468 


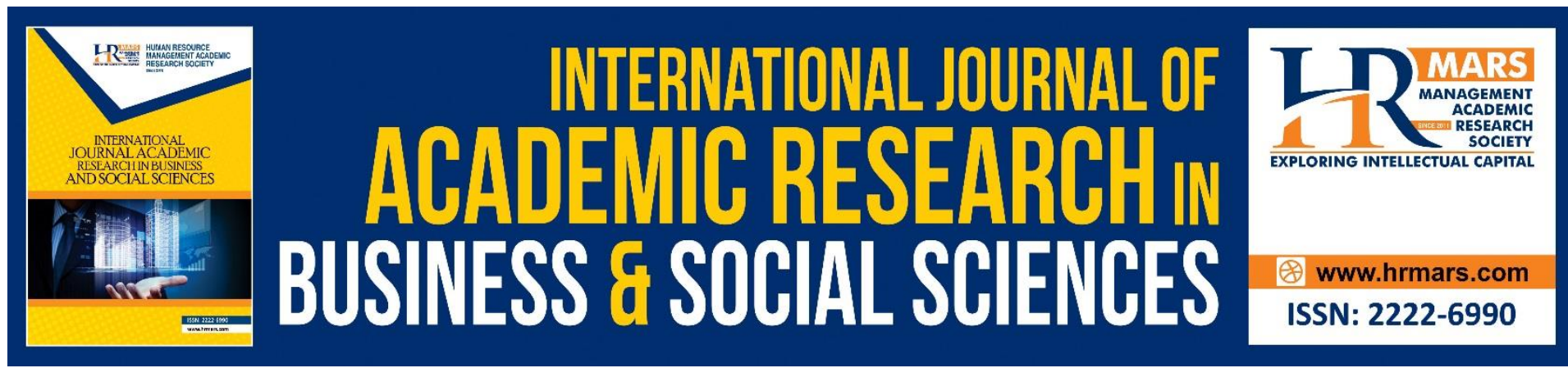

\title{
Exploring the Relationship between Writing Anxiety and the Pedagogical Use of Online Learning Medium among Malaysian University Students
}

\author{
Siti Faridah Kamaruddin ${ }^{1}$, Imelia Laura Daneil ${ }^{2}$, Assoc. Prof. Dr. \\ Tang Howe Eng ${ }^{3}$ \\ ${ }^{1}$ Academy of Language Studies, Universiti Teknologi MARA, Sarawak Branch, Mukah \\ Campus, ${ }^{2}$ Academy of Language Studies Universiti Teknologi MARA, Sarawak Branch, Mukah \\ Campus, ${ }^{3}$ Faculty of Computer Science and Mathematics \\ Universiti Teknologi MARA, Sarawak Branch, Mukah Campus \\ Email: faridah8543@uitm.edu.my, imelialaura@uitm.edu.my, lily@uitm.edu.my
}

\begin{abstract}
According to United Nations in 2020, the pandemic of COVID-19 has caused the largest disruption of education systems in history. The sudden transition from traditional classroom to online classroom has caused many students to become anxious with their learning especially when they have to learn writing skills through several online mediums such as instant messenger (e. g. Whatsapp and Telegram), social media (e. g. Facebook, Instagram, Twitter and YouTube), live meeting session (e. g. Google Hangouts Meet, Zoom and Cisco Webex) and education tools (e. g. Google Classroom, Padlet and Kahoot). To address this issue, this qualitative study explored the reported experience of nine students from Diploma of Banking Studies who are taking the writing course through an online medium, namely Telegram. The students are prompted with a list of interview questions focusing on writing anxiety. Their responses were analysed, and two major themes were generated. The results revealed that the participants in this study described external and internal reasons as the causal factors to their writing anxiety. The internal reasons can be classified further into somatic anxiety, cognitive anxiety, and avoidance behaviour. The participants suggested a few major coping strategies to overcome their writing anxiety such as taking a deep breath, taking some time off from writing task, getting some entertainment and practising relaxation. Keywords: Writing Anxiety, Causal Factors, Coping Strategies, Qualitative Approach, Online Learning Medium
\end{abstract}

\section{Introduction}

A disease that is endemic to almost all countries in the world, Corona Virus Disease or COVID19 was declared a pandemic on March 11, 2020 (Ducharme, 2020). According to the Center for System Science and Engineering (CSSE) at Johns Hopkins University (JHU), this virus 
spreads very fast and it was recorded that 185 countries in the world had contracted COVID19. The World Health Organization (WHO) recommends several steps for curbing the spread of COVID-19 by implementing travel restrictions, quarantine, and curfew restrictions, controlling workplace hazards, and closing public facilities. This pandemic has caused disruption which is severe in various social and economic fields. The education sector is also experiencing significant disturbance. Schools and universities have been closed, both nationally and locally in numerous countries with COVID-19. The solutions which are currently offered are by doing online learning from home. Lecturer as one of the components in higher education must be able to facilitate students to continue lectures, deliver material and even an assessment system.

Online learning presents several benefits to students such as targeted course offerings, curriculum development, student learning outcomes, behavior and process, personalized learning, improved instructor performance, post-educational employment opportunities, and enhanced research in the field of education (Avella, Kebritchi, Nunn \& Kanai, 2016). According to Davies and Graff (2005), students can easily have topic-focused discussions similar to a traditional classroom. Furthermore, online learning provides convenience and flexibility for lecturers and students in determining the appropriate time for their teaching and learning activities to take place without considering about the barrier of location (Bower et al., 2015).

Teaching and learning activities are also now closely related to the concept of Big Data as these activities can be tracked and stored within the online environment. According to Picciano (2012), Big Data refers to the capability of storing large quantities of data over an extended period and down to particular transactions. These big data can be traced through several mediums such as instant messenger (e. g. Whatsapp and Telegram), social media (e. g. Facebook, Instagram, Twitter and YouTube), live meeting session (e. g. Google Hangouts Meet, Zoom and Webex) and education tools (e. g. Google Classroom, Padlet and Kahoot). These mediums assist teaching and learning as they provide a medium for lecturers to deliver materials and assessments as well as for students to receive and submit their completed tasks. Learning Management Systems (LMS) as stated earlier are capable to provide online content which can support distance learning as the teaching and learning materials can be accessed anytime and anywhere (Vieira, Lopes \& Suares, 2014).

This research has conducted a qualitative study for investigating the writing anxiety experienced among Diploma students when they are taking a writing course for a semester through online learning medium. The online interview was conducted to obtain information about the reported experience regarding writing anxiety from a group of students who are taking writing course through online learning medium during the social distancing period in order to prevent the spread of COVID-19. This study is guided by the following research questions:

1. What are the causal factors of writing anxiety when the students take writing course through online learning medium?

2. What are the strategies that can be implemented to cope with writing anxiety based on students' experience?

\section{Literature Review}

The concept of writing anxiety was considered as an important topic for understanding the correlation between this language difficulty and human characteristics (Daly \& Miller, 1975). It was discovered that writing anxiety has pertinent characteristics as compared to the 
general language anxiety. Daly (1978) explained that in the process of active encoding written messages, people or students in this case, will react differently in their apprehension. Writing apprehension or writing anxiety as it was interchangeably used, is conceived as a situation and subject-specific individual difference (Daly \& Miller, 1975). It depends whether the students might approach or avoid situations which demanded writing and it was made worst when it was accompanied with a certain amount of evaluation. If a student possesses a high level of writing anxiety, he or she will find the writing task as unrewarding. Thus, in this occurrence, the student will tend to avoid the writing task if it is perceived as required. Consequently, writing anxiety is developed within students' affective state more than the normal amount of anxiety which students should experience as they are worried of their capability for doing what is expected in a language classroom and this anxiousness is inevitable among language learners.

Writing anxiety not only removes the fun from writing tasks, but it can also affect students to commit a certain amount of interlanguage errors in their writing. Interlanguage can be defined as the language system of the second language learner, a system distinct from both the native as well as the target language (Selinker, 1977; as cited in Fauziati, 2003). The language systems comprised of first language and target language elements. Writing anxiety and interlanguage errors are related due to several reasons, namely foreign language learning is a process of hypothesis testing and errors committed by learners are caused by L1 through negative transfer (Türnük \& Aydin, 2020). In other words, students who are less proficient in English language prone to depend heavily on their mother tongue or native language as they write (because they are translating their writing idea from $L 1$ to $L 2$ ), and the anxiety comes in when they are worried if what they are writing is accepted or not by their lecturers, especially if their writing work is being evaluated.

These current studies in relation to writing anxiety have been done extensively by tapping into different backgrounds among language learners. Firstly, Rabadi and Rabadi (2020) discussed this phenomenon among medical students and they have identified several causes to writing anxiety such as linguistic difficulties, insufficient writing practice, low selfconfidence in writing, and fear of writing tests. Secondly, Mohamed Kassem (2017) proposed the use wikis to develop business writing skills among Business Administration students. Thirdly, Sivaci (2020) investigated the use of peer feedback among pre-service teachers in the effort to improve writing performance. Fourthly, Liu (2020) assisted adult EFL learners by reducing writing anxiety which hampers their writing performance through the implementation of sentence-making practice. By referring to these studies, it indicates that the studies conducted on writing anxiety is still very much relevant up to these point of time as it is perceived that no language learner can be excluded when it comes to the expectation of creating a writing product in a language which is not their first or native language. Besides that, the previous studies done by these researchers are investigating different background of learners, however these learners are studying physically in a traditional language classroom whereas there is lack of literature in studying the indication of writing anxiety among students who are studying completely through online learning medium. The abrupt transition from conventional language classroom to online learning medium is a consequence from the spread of COVID-19. 
The study of writing anxiety mainly revolves around the causal factor of its manifestation and its coping strategies. In the first section, these past studies show some of the factors that trigger students to experience writing anxiety. Firstly, Syarifudin (2020) listed linguistics difficulties, lack of topical knowledge, and insufficient writing technique as the dominant sources of writing anxiety among EFL learners. Secondly, Mat Daud, Mat Daud and Abu Kassim (2005) revealed how anxiety is related to performance using the deficit hypothesis. The subjects in their study suffered anxiety because of their lack of writing skills, and that the better students experienced less anxiety than the weaker ones. Many previous studies on the deficit hypothesis claimed that the inability of students to perform well especially with their writing skill is caused by insufficient developed skill. Writing anxiety is a result from cognitive and linguistic disability which leads to poor writing performance (Sparks, Ganschow \& Javorsky, 2000). In contrast, writing anxiety can be a sole interference with writing ability, thus the deficit hypothesis may occur to some circumstance of writing anxiety, but not all of it (Horwitz, 2000; as cited in Mat Daud, Mat Daud \& Abu Kassim, 2005). Thirdly, Jawas (2019) identified factors contributing to writing anxiety from different dimensions, such as essay writing process, types of essay assignment and the classroom atmosphere. Students in Jawas's study felt anxious during essay writing process when they had to arrange ideas to develop the content of the essay, when they had to decide the thesis statement of their essay, and when they had to develop the content of the essay. Next, the types of essay assignments that potentially cause the students to feel most anxious are that of individual essay assignment done in the class with the topic decided by the lecturer and within time restriction. Lastly, in terms of classroom atmosphere, the lecturer is the one of the classroom atmosphere factors that is likely to produce anxiety to the students while their classmates have equal chance to cause them to feel anxious or not.

Among these causal factors which have been recorded earlier, the learner or students themselves, constitutes as one of the important factors that contributed to writing anxiety as it is prominently associated with the concept of self-efficacy. Firstly, Aytaç-Demirçivi (2020) investigated students' writing achievement and writing self-efficacy and these influence their writing anxiety level. Secondly, Soleimani, Hamasaid and Saheb (2020) explored the predictability of global L2 writing performance by probing the affective and linguistic variable of $\mathrm{L} 2$ writing anxiety, writing self-efficacy, and writing motivation. The results from their study indicate that writing self-efficacy and writing motivation has a positive and significant relationship with global L2 writing performance while L2 writing anxiety was a different variable from them, indicating a significant but negative correlation with L2 writing performance. Thirdly, Sabti, Md Rashid, Nimehchisalem and Darmi (2019) examined learner factors by looking at individual differences such as anxiety, self-efficacy, and achievement motivation in ESL/EFL writing. Studies have affirmed that self-efficacy and achievement motivation could enhance writing performance, whereas anxiety may hinder writing achievement. Based on these previous studies, it can be concluded that having a higher level of self-efficacy would produce a better writing performance while at the same time; it is negatively influenced by writing anxiety.

Hence, in the effort to reduce the negative impacts of writing anxiety, this second section then listed several previous studies which have been conducted to serve this purpose. Positive changes can be seen with the implementation of online gamification tool such as Edmodo (Yavuz, Ozdemir \& Celik, 2020), the writing process approach (Kurniasih, Sholihah, 
Umamah \& Sung, 2020), portfolio-based writing instruction (Fathi, Derakhshan \& Safdari, 2020), collaborative writing (Haji Jalili \& Shahrokhi, 2017), the employment of critical thinking in writing (Saedpanah \& Mahmoodi, 2020), the utilization of writing strategies such as affective and metacognitive strategy (Masriani, Mukhaiyar \& Wahyuni, 2018) and the proposal of a writing instructional model (Tsiriotakis, Vassilaki, Spantidakis \& Stavrou, 2017). However, these are the coping strategies to assuage writing anxiety as proposed by the researchers and lack of students' voice are heard to identify what are the coping strategies that they have employed and proven successful to them throughout their writing course, especially when it is done fully online. Therefore, this study is significant as it will shed light on the relationship between writing anxiety and online learning medium, apart from tapping into detail of the causal factors which contribute to writing anxiety and coping strategies of alleviating writing anxiety coming from the language learners themselves based on their experience.

\section{Problem Statement}

Writing anxiety has been known to have detrimental effects on students' academic performance. According to Martinez, Kock and Cass (2011), students with lower level of writing anxiety are reported to have higher GPAs. In the opposite situation, Abu Shawish and Atea (2010) mentioned that high achievers in writing courses were more apprehensive than low achievers. These situations indicate that when discussing about academic performance in general, the lower level of anxiety will produce students with better grades with subjects that require writing. However, when observing specifically at writing course, the students who are proficient in writing are experiencing greater anxiety as they feel pressured to produce their writing task at a certain standard.

The situation discussed earlier is when the writing anxiety experienced by students as they are taking writing course in a conventional language classroom where there are sufficient interactions between students and their lecturers or students and their peers. When technology is fully integrated for writing courses especially during the times of need such as the surge of the worldwide pandemic, students and lecturers are left with no choice to conduct teaching and learning activities in separate learning environments while trying to reach the outcomes of the writing course. Previous studies such as Abu Shawish and Atea (2010) have explored the level of writing anxiety with the use of computer in writing activities. However, they found that computer use in writing played no significant role neither in the students' estimates of the causes nor of the remedies of writing apprehension. Eventually, if given choice without considering the current situation influenced by the pandemic, students found traditional collaborative writing seems to be more effective than blog-supported collaborative writing (Wu, 2015).

As contrasted with the two studies stated earlier, Foroutan and Noordin (2015) discovered that e-mail has potential to assist students in lowering their anxiety towards learning. In addition, the respondents in the study conducted by Hussin, Abdullah, Ismail and Yoke (2015) perceived that there was a positive effect of on their writing performance and improvement on their writing anxiety level particularly through the use of Computer Mediated Classroom (CMC) applications. These two studies have shown that writing anxiety experienced by the students can be alleviated with the use of technology during the writing course. In comparison with the previous studies listed earlier, it shows a contradicting effect on the use of technology in writing course as it can have either negative or positive influence on students when they are learning the required writing skills via online medium. 
Hence, the current research aims to contribute to the literature by investigating the reported experience of writing anxiety faced by Diploma students when they must learn writing skills through online learning medium. The research objectives are as follow:

3. To identify the causal factors of writing anxiety when the students take writing course through online learning medium

4. To propose the strategies implemented to cope with writing anxiety based on students' experience.

\section{Methodology}

The study aims at exploring the relationship between writing anxiety among Malaysian university students and pedagogical design of online learning medium in an English writing classroom. This study is adopting an exploratory case study approach (Merriam, 1998; as cited in Zhang, 2019). To investigate research questions which deals with perceptions and reported experiences, it is best to employ qualitative research design as the participants are probed to understand how their experiences are interpreted, how their worlds are constructed and how their meaningful experiences are attributed (Merriam, 2009; as cited in Miri \& Joia, 2018).

The participants for this research were nine Malaysian non-English majors, namely Diploma in Banking Studies, consisting of four male and five female students. The participants were chosen using purposeful sampling. The participants were all ESL learners, and they had the experience of taking one writing course via open and distance learning (ODL) due to the outbreak of COVID-19 pandemic in the semester of March until July 2020. The demographic information of the participants is demonstrated in the following table:

Table 1: Participants and Demographic Information

\begin{tabular}{lllll}
\hline Name & Gender & Race & Age & $\begin{array}{l}\text { Location while attending ODL } \\
\text { (in Sarawak, Malaysia) }\end{array}$ \\
\hline Mr. AK & Male & Iban & 23 & Saratok \\
Miss AA & Female & Kayan & 21 & Miri \\
Miss C & Female & Iban & 20 & Miri \\
Mr. G & Male & Iban & 20 & Sibu \\
Miss M & Female & Iban & 20 & Kapit \\
Miss N & Female & Iban - Bidayuh & 20 & Miri \\
Mr. H & Male & Melanau & 20 & Dalat \\
Miss P & Female & Malay & 21 & Serian \\
Mr. R & Male & Iban & 21 & Selangau \\
\hline
\end{tabular}

The data from the participants was collected using online-based interview. A set of interview questions were adopted from previous study by Miri and Joia (2018). The participants were sent with these interview questions via Telegram and they were given a week to write their response based on the questions. After they completed the interview by writing their responses on Microsoft Word, their responses were emailed to the researcher. 
Next, the data were analysed inductively and recursively through qualitative content analysis (Neuendorf, 2016; as cited in Zhang, 2019). The transcribed data was read many times and directed by the research objectives. From the data transcription, codes deduced from relevant literature which focuses on writing anxiety and online learning mediums. Finally, these codes were categorised into two major themes. The accuracy of the data was validated by conducting member checking and external audit. The researcher asked the participants to check the accuracy of the account by sharing the finding of this study. Subsequently, this study was also reviewed by an experienced qualitative expert who identified the strengths and weaknesses of this study.

\section{Findings and Discussions}

This study is conducted with the main objective of exploring the reported experience of writing anxiety experienced by the students who took a writing course through online learning medium. The two major themes which will be discussed in this section are the causal factors which are responsible in the manifestation of writing anxiety and the suggested coping strategies as implemented by the participants to alleviate their writing anxiety.

\section{The Causal Factors for Writing Anxiety}

The reasons which trigger writing anxiety among participants can be classified into external and internal factors. External factors are the factors which students cannot control and become a result based on their response towards writing anxiety; either it is a positive or negative reaction. These examples as stated by Miss $\mathrm{N}$ and $\mathrm{Mr}$. $\mathrm{R}$ in the interview respectively have demonstrated that the students cannot control the classroom procedure as practiced by their lecturer or the noise which disturbs students' focus to write.

Miss N: My mark for the essay will drop and doesn't have enough time to do the essay and yes, it is important to take lesson from it because I don't like my English test paper get a lower marks.

Lin and Ho (2009) raised the issue of teacher's evaluation as students' anxiety might be aggravated due to face problems when thinking of teacher's negative comments or low score graded for them

Mr. R: The causes behind the anxiety I have felt is environment factor such as sound of cars because my house near with the highway. And this factor will give effect on my writing skill because it will disturb my mind while I write. Sometimes it can remove all my idea before do writing.

Vonderwell and Zachariah (2005) stated the factors which influence online learner participation and patterns of participation are technology and interface characteristics, content area experience, student roles and instructional tasks, and information overload. In addition, Keskin and Yurdugul (2019) specified that there is a correlation between the preferences of the learning environment, and the constructs of self-efficacy, e-learning motivation, and task value. It can be said that the motivational variables are more effective in the learning environment preference. The students with high task value, e-learning motivation, and self-efficacy preferred studying in blended learning environments. Cognitive strategies, self-directed learning, learner control, and test anxiety factors are independent of 
the learners' learning delivery preferences. These two studies are discussing mainly on the environment in reference to online learning medium but in the case of Mr. $\mathrm{R}$, the environment discussed here is about the physical learning environment in terms of the location where the students are studying online.

Apart from Miss $\mathrm{N}$ and Mr. R, 7 out of 9 participants gave internal reasons as cause to their anxiousness in writing. Internal factors encompass cognitive ability, affective elements, or students' own writing motivation (refer to Yu, Zhou, Zheng, Zhang, Cao \& Li, 2019). These internal factors are parallel to what Cheng (2004) has proposed on types of writing anxiety, namely somatic anxiety, cognitive anxiety, and avoidance behaviour.

Firstly, somatic anxiety is the physiological effect of the anxiety experience as reflected in increased autonomic arousal and unpleasant feeling states such as nervousness and tension. Due to somatic writing anxiety, it has contributed the feeling of lack of confidence among some of the participants. This can be shown in the following responses by Miss AA and Miss C:

Miss AA: Yes, because I'm not confident sometimes due to my English is broken and I need to translate some words that I do not know the meaning of it

Miss C: $\quad$ For reasons I feelings that I the one of stupid or losers students, it's happen starting from my pointer result at Semester 1, because of that I am not confident anymore on any subject (including English), I always worry for that. For this reason I think yes, it is really important on my writing skill because every time I think about my nightmare (pointer Semester 1) I will try my best to do it well even have a little bit worry, but I don't want that accident happen again so I will push myself to do that until I feel stress.

Zhang (2011) as well as Rezaei and Jafari (2014) explained that students' frustration may come from high expectations of the writing objectives but low self-confidence in the achievement in English writing. From the interview, Miss $C$ especially has given a clear example in which the negative experience she has received from her previous language teacher and her result from Semester 1 which has caused frustration, thus causing her to lose the confidence whether she can be good in writing or vice versa. Choi (2013) assumed that the source of students' lack of confidence and uncertainty might come from previous L1 writing experience or L2 writing experience. However, it is clear that many students were not confident enough to write in English and took writing not as an enjoyable communication between a writer and a reader but as a demanding test.

Secondly, cognitive anxiety refers to the mental aspect of anxiety experience, including negative expectation, pre-occupation with performance, and concern about others' perception. Most participants have given clear examples related to cognitive writing anxiety. The first example of how writing anxiety has deterred the cognitive process among students is lack of ideas and vocabulary. As Mr. AK said in the interview:

Mr. AK: Because of lack in ideas and also lack in vocabulary. 
The second example of cognitive writing anxiety is afraid of doing mistakes such as grammar. This can be illustrated by Mr. G. in his response:

Mr. G: I think one of the causes of the writing anxiety is the afraid of doing a mistake such as grammatically error.

Jebreil, Azizifar and Gowhary (2015) stated that there is significant difference in grammar and punctuation subscales of writing performance between males and females. Interestingly, their study indicated that males were higher than that of females in the effect of anxiety on grammar and punctuation subscales. This has been proven true as only male participants in this study has given the response based on writing ideas and grammar mistakes, and none from female participants.

Consequently, students are hindered by the writing knowledge which they need to master prior producing a writing piece such as vocabulary and grammar as what have been mentioned by Mr. AK and Mr. G. Thus, it will further lead to students' belief that they need to write the most preferable things for others to read. This can be demonstrated by a response given by Miss $P$ :

Miss P: The main reason for me experiencing anxiety and stress is because I always want to write the most preferable things for others to read. I feel very happy when people are pleasure to read my writing. That is why I always put pressure on myself to be good in writing.

Some students felt that writing in English was a demanding task because they could not express their thoughts clearly owing to a lack of sufficient vocabulary. However, as can be seen from Miss P's response, she finds pleasure when other people enjoy her writing and hence, putting the writing pressure on herself in order to do so. Choi (2013) pointed out that there is a large gap between the students' current vocabulary size and the vocabulary size the students felt was necessary for the writing task. Another assumption that Choi made was the students had greater receptive vocabulary knowledge than productive vocabulary knowledge, considering some students' struggle to find the words they wanted.

Finally, another example of cognitive writing anxiety is when a student felt that he/she is lacking in terms of writing preparation. As reflected by Miss M:

Miss $\mathrm{M}$ : The reasons behind the anxiety that I felt are not prepare for the writing courses and cannot focus on one thing only.

As mentioned by the anxious learners in Nazari, Farnia, Ghonsooly and Jafarigohar's (2019) study, they believed that writing courses do not take learners' preparation into consideration and this can eventually cause to writing anxiety.

Thirdly, avoidance behavior deals with behavioral aspect of students regarding writing. Interestingly, Mr. $\mathrm{H}$ has illustrated reverse avoidance behaviour and can be illustrated in his following response: 
Mr. H: Whatever the reason is, it always has high probability that the cause (of writing anxiety) is from myself.

He further added that his attitude towards writing is the first step for him to like writing, and this positive behaviour will reduce the anxiety. When he has a positive behaviour towards writing, he will not avoid writing task and thus writing anxiety will not or less likely to occur. On the same note intended for students' attitude towards target language based on a previous study conducted by Teksan (2013), it is found those students who love Turkish lesson changes significantly. Since loving the lesson requires taking care and not making mistakes, this situation can create anxiety for students. Huang (2006) relates the relationship of writing anxiety with students' attitude towards writing together with motivation. Huang found that students' attitude and motivation are moderately correlated, but these two variables do not correlate to writing performance. There are also no significant differences of writing performance with varying levels of motivation.

5 out of 9 participants mentioned that by identifying these external and internal reasons to their writing anxiety can positively encourage them to find solution to their anxiousness or seek help from others, focus on what needs to be written, be aware of their writing performance, start their interest in writing, and produce an effective writing piece where readers can understand what they have written.

\section{The Coping Strategies to Alleviate Writing Anxiety}

In this section, it deals with the participants who have practiced different coping strategies for decreasing their anxiety level in the writing courses taken via online learning medium this semester. The participants suggested four main ways to alleviate their anxiety while completing their writing task.

The first suggested way to alleviate writing anxiety is taking a deep breath when they sprawled with some difficulty while writing. The following responses demonstrated how some participants attempt to reduce their anxiety through this technique:

Mr. AK: Take a deep breath and take a break and finally find any solution.

Miss N: I always try to take a deep breath and calm down even clear my mind for a bit so that I don't waste a lot of time while panicking

Miss P: If I have anxiety during the courses, I will close my eyes for a while and take a deep breath

Secondly, these participants recommended taking some time off from task as their way of alleviating their writing anxiety. The interview excerpts are as follow:

Mr. AK: Take a deep breath and take a break and finally find any solution.

Miss C: I will do like other students always do, take 10 minutes to cool down myself

Miss P: If I still have it (writing anxiety), I will distract myself for a while from writing and do other stuff to give myself a space and continue the writing later.

Mr. R: And also stop to do task for a while in 5 to 10 minutes to calm my mind. It will help me a little bit to feel fresh before continuing do my task. 
Thirdly, these participants also stated that they tried to alleviate their writing anxiety by getting some entertainment from games, music, or movies as mentioned in their interviews:

Miss C: listen to my favourite music

Mr. G: if I have anxiety during the courses, I will play some games to ease the tension. Plus, I will listen to some music. Lastly, watch some movies.

Mr. R: When I have anxiety during my course, I try my best to relaxing myself. For example, listening to music.

Fourthly, Miss $\mathrm{M}$ and Miss $\mathrm{P}$ advocated relaxation if they are experiencing writing anxiety as they reflected through these excerpts:

Miss M: When I have anxiety during my courses, I will relax my mind and only focus on the courses.

Miss P: I will give myself a little time to relax so that I can think. This really work on me most of the time.

Lastly, there are other ways to alleviate their anxiety based on individual responses such as searching for information on Google, crying, drinking some mineral water, and seeking help from lecturer. The excerpts of their responses are as follow:

Miss AA: Search on Google to know some main point about the title given

Miss C: If that day I really can't control myself I will cry in room.

Miss $\mathrm{M}$ : I will drink mineral water to calm down. It is because drink mineral water can make me more focus and calm.

$\mathrm{Mr} . \mathrm{H}$ : If I ever have to face anxiety, I will approach my teacher to ask for some advice

The findings on the coping strategies as practiced by the participants in this study is corroborated with a previous study by Qashoa (2014) which indicated the coping strategies as viewed by the students and teachers in the mentioned study. The coping strategies found by Qashoa is simplified into the following table below: 
Table 2: Coping Strategies from the Perspectives of Students and Teachers (Qashoa, 2014)

\begin{tabular}{|c|c|c|}
\hline Types of Strategies & Students' Perspectives & Teachers' Perspectives \\
\hline General strategies & 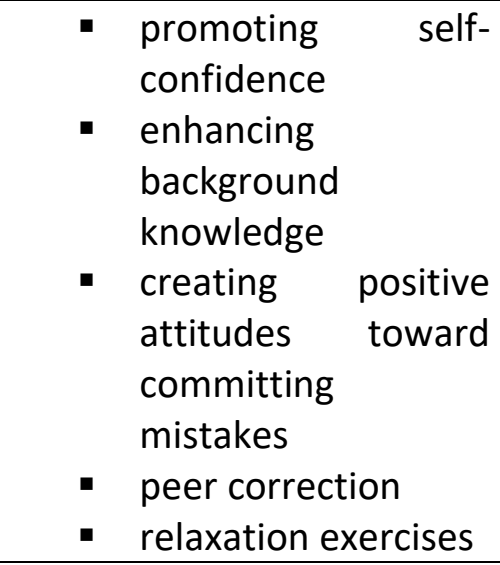 & 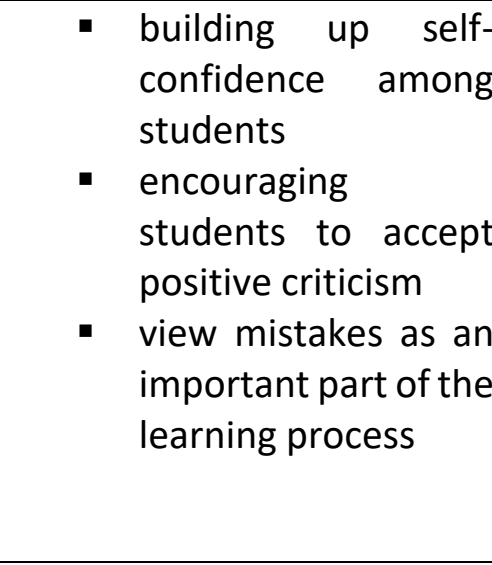 \\
\hline Cognitive strategies & 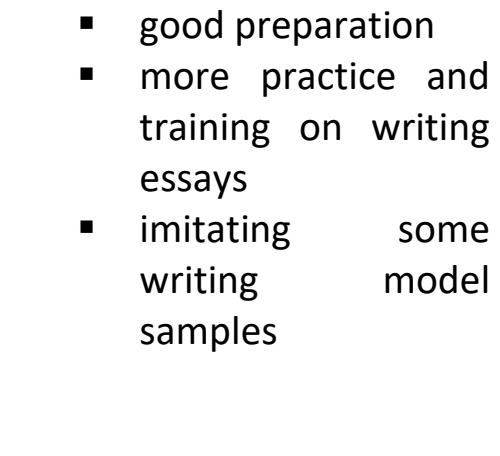 & $\begin{array}{l}\text { - } \text { adopting process } \\
\text { writing approach } \\
\text { - } \text { tolerating slight } \\
\text { grammatical and } \\
\text { spelling mistakes } \\
\text { - providing students } \\
\text { with lists of most } \\
\text { common English } \\
\text { words. }\end{array}$ \\
\hline Test related strategies & $\begin{array}{l}\text { - } \begin{array}{l}\text { rehearsing some } \\
\text { tests }\end{array} \\
\text { - taking mock exams } \\
\text { - learning the task of } \\
\text { outlining } \\
\text { - guessing the prompt } \\
\text { difficult words } \\
\text { - using dictionaries in } \\
\text { writing tests }\end{array}$ & $\begin{array}{l}\text { - limiting the } \\
\text { keywords in writing } \\
\text { prompts to familiar } \\
\text { English words } \\
\text { - training students on } \\
\text { taking tests under } \\
\text { time pressure } \\
\text { - making more non- } \\
\text { judgmental tests }\end{array}$ \\
\hline
\end{tabular}

\section{Conclusion and Implications}

This case study investigated the impact of conducting writing course through an online learning medium associated with students' writing anxiety. The participants resonate positive responses about taking writing course over online learning medium such as instant messenger, namely Telegram as it has been used by the participants throughout this semester. Overall, this study yields the following findings.

Firstly, the participants in this study have identified the causal factors which have triggered their writing anxiety from the online learning medium. The external factors identified are classroom procedure and learning environment while participating in open and distance learning. As for internal causal factors, it can be further classified into three other types which are somatic writing anxiety, cognitive writing anxiety and avoidance behaviour. The causal factor from somatic aspect is lack of confidence due to language ability and academic performance. The causal factors coming from cognitive aspect has produced several reasons behind the manifestation of writing anxiety including lack of ideas and vocabulary while writing, afraid of grammatical errors, feeling pressured to write what is preferred by the 
reader and lack writing preparation. In terms of avoidance behaviour, the attitude towards target language for writing is acknowledged as the cause of writing anxiety.

Secondly, by exploring the writing anxiety experienced by students while taking writing course through online learning medium, this study contributed to existing research on alleviating students' writing anxiety by identifying the coping strategies which has been used by the participants in this study while going through open and distance learning in this current semester and it has been proven successful based on self-reported experience by these participants. Some of the coping strategies employed by the participants are taking a deep breath when experiencing anxiety, taking a short break when facing difficulty with writing task, getting some entertainment, and practising relaxation.

Thirdly, there are several limitations to this study which need to be accredited. Firstly, the results from this qualitative study cannot be generalised to other students who are taking writing course via online learning medium. A quantitative study can be conducted in order to collect data from a larger sample. Secondly, it is also worthwhile to explore the perceptions of lecturers who are teaching writing skills via online learning medium. The lecturers can share what are the practices that they have implemented in their online writing classroom in the semester which can either facilitate or impede the process of teaching and learning. Hence, their challenges and recommendations in alleviating writing anxiety via online writing classroom should be made known so it can help other lecturers who are facing difficulty to adjust themselves in the transition of traditional writing classroom into an online classroom with virtual participation from students. Finally, it is also discovered that there is a need to conduct a study on the factors of online learning participation or preference, which is not only by looking at the online medium per se, but taking students' physical environment into consideration as well. This factor needs to be studied as it will also contribute to the manifestation of writing anxiety if it is not addressed.

Fourthly, this study brought some pedagogical implications to these following dimensions. The first dimension constitutes of a strategy of instructional model design to promote strategic behaviour, knowledge, and motivation in writing courses especially in considering this instructional model in an online learning medium. Harris, Graham and Mason (2006) suggested a strategy of instructional model designed to promote development in the areas of strategic behaviour, knowledge, and motivation through the introduction of self-regulated strategy development (SRSD) which their main focus is on planning and writing stories and persuasive essays. They have also added peer support as an additional component to SRSD which aimed at facilitating maintenance and generalization effects. According to Zimmerman (1990), self-regulated learning can be another way to reduce the writing anxiety as students have a greater control of their own learning, thus eliminating factors that can contribute to language anxiety such as tolerance of ambiguity and risk taking.

The second dimension discussed on fostering the self-efficacy in writing among students. Selfefficacy in writing can also be increased through the implementation of cooperative learning in enhancing writing performance (Ismail \& Tengku Mohamad Maasum, 2009; Keshavarz, Shahrokhi \& Talebi-Nejad, 2014). Additionally, M. Shah, Wan Mahmud, Din, Yusof and Mat Pardi (2011) conducted a study to examine English language learners' self-efficacy in writing among Malaysian secondary school students learning English. Self-efficacy is the key to promoting students' cognitive, behavioural, and motivational engagement, which demonstrates the importance of its role in the development of writing competence. Their study also examined the relationship between the learners' self-efficacy and their writing performance and competence. They believed that individuals, who hold positive perceptions 
of themselves as good writers are more likely to pursue opportunities to write, expend more effort during their writing process and demonstrate greater persistence in seeking writing competence generally. Thus, a high sense of self-efficacy is likely to contribute to the production of good-quality writing, as opposed to low self-efficacy.

As for the third dimension, Choi (2013) posited that if lecturers carefully design more writing tasks that consider students' proficiency levels in English as well as previous L1 and L2 writing experience, and if they provide learning aids such as teaching common expressions and giving supportive feedback, students themselves may see writing as a less discouraging and more pleasant experience in the classroom. As Choi (2013) discussed on traditional writing classroom, Borgman and Dockter (2018) clarified the same matter in the context of online writing classroom. The lecturers should also consider the access and design in the online writing classroom. Lecturers can use user-centred design in online courses to accommodate all students with varying learning styles. User-centred design is significant as it can be crucial for maintaining student enrolments, promoting learning, and avoiding attrition.

In the fourth dimension, dialogue journal writing is suggested to be implemented in a writing course through the online learning medium. Malaysian researcher such as Thevasigamoney and Md. Yunus (2014) have also displayed their interest in following the research trail by their other counterparts in Taiwan such as Liao and Wong (2007) on incorporating dialogue journal writing as the method to not only reduce writing anxiety but also to improve writing fluency, reflections and intrinsic motivation. Liao and Wong (2007) have displayed their findings due to positive attitudes held by the students toward the dialogue journal writing project as the project has successfully improved the students' writing fluency; writing performance on content, organization, and vocabulary; reflective awareness of writing and self-growth as learners; as well as intrinsic writing motivation and most importantly in reducing their writing anxiety. Furthermore, the dialogue journal writing project allowed the students to consider something new; enhanced their self-confidence so that they could get along better with others; matured them through sharing their ideas, feelings, and self-perceptions; consolidated their thinking when re-reading their journals; strengthened their confidence in English writing; and gave them the chance to reflect on their daily lives. On the other hand, Thevasigamoney and Md. Yunus (2014) conducted dialogue journal writing in a slightly different medium which is through the application of e-mail. They found that the application of this method for the gifted learners have reduced the writing anxiety that they experienced despite that they are not that highly anxious in writing.

Lastly, Abdous (2019) suggested online learning orientations to define students' feelings of anxiety by clarifying course expectations and requirements while boosting their selfconfidence and preparedness. This is vital as online students are transitioning abruptly from a face-to-face to an online learning environment and hence, online students are likely to feel anxious about their ability to succeed in what could be an unfamiliar learning environment. Some of the factors associated with the online learning experience are students' demographics, prior online learning experience, satisfaction, and sense of preparedness for the course after completing an online learning orientation which influence online students' feelings of anxiety. Students' age and satisfaction were less conclusive in predicting online students' feeling or anxiety. These factors need to be identified as these factors will influence the measures that needs to be taken boost their confidence, motivation, and preparedness to succeed in online courses. 


\section{Acknowledgements}

We would like to thank the interviewees who are the students from Diploma of Banking Studies, March - July 2020 semester, for their detailed and honest responses.

\section{References}

Abdous, M. (2019). Influence of satisfaction and preparedness on online students' feelings of anxiety. The Internet and Higher Education, 41, 34-44.

Abu Shawish, J., \& Atea, M. (2010). An Investigation of Palestinian EFL Majors Writing Apprehension: Causes and Remedies. Proceedings of the First National Conference on: Improving TEFL Methods \& Practices at Palestinian Universities, Oct. 20, 2010. http://www.qou.edu/english/conferences/firstNationalConference/pdfFiles/drJaberDr Mohammad.pdf

Avella, J. T., Kebritchi, M., Nunn, S. G., \& Kanai, T. (2016). Learning Analytics Methods, Benefits, and Challenges in Higher Education: A Systematic Literature Review. Online Learning, 20(2), $13-29$.

Aytaç-Demirçivi, K. (2020). Personal factors predicting EFL learners' writing anxiety. Global Journal of Foreign Language Teaching. 10(4), 257-267.

Borgman, J., \& Dockter, J. (2018). Considerations of Access and Design in the Online Writing Classroom. Computers and Composition, 49, 94-105.

Bower, M., Dalgarno, B., Kennedy, G. E., Lee, M. J. W., \& Kenney, J. (2015). Design and implementation factors in blended synchronous learning environments: Outcomes from a cross-case analysis. Computers \& Education, 86, 1- 17.

Cheng, Y. S. (2004). A measure of second language writing anxiety: Scale development and preliminary validation. Journal of Second Language Writing, 13, $313-335$.

Choi, S. J. (2013). Language Anxiety In Second Language Writing: Is It Really A Stumbling Block? Second Language Studies, 31(2), 1-42. Retrieved from http://www.hawaii.edu/sls/wpcontent/uploads/2014/09/Choi-Sujeong.pdf

Daly, J. A., \& Miller, M. D. (1975). The Empirical Development of an Instrument to Measure Writing Apprehension. Research in the Teaching of English, 9(3), $242-249$.

Daly, J. A. (1978). Writing Apprehension and Writing Competency. The Journal of Educational Research, 72(1), 10-14.

Davies, J., \& Graff, M. (2005). Performance in e-learning: online participation and student grades. British Journal of Educational Technology, 36(4), $657-663$.

Ducharme, J. (2020). World Health Organization Declares COVID-19 a 'Pandemic.' Here's What That Means. Retrieved $3^{\text {rd }}$ January 2021 from https://time.com/5791661/whocoronavirus-pandemic-declaration/

Fathi, J., Derakhshan, A., \& Safdari, M. (2020). The Impact of Portfolio-Based Writing Instruction on Writing Performance and Anxiety of EFL Students. Polish Psychological Bulletin, 51(3), $226-235$.

Fauziati, E. (2003). Interlanguage Errors in English Textbooks for Junior High School Students in Surakarta. TEFLIN Journal, 14(2), 179 - 192.

Foroutan, M., \& Noordin, N. (2015). Effect of Dialogue Journal Writing through the Use of Conventional Tools and E-mail on Writing Anxiety in the ESL Context. English Language Teaching, 5(1), $10-19$.

Jalili, H. M., \& Shahrokhi, M. (2017). The Effect of Collaborative Writing on Iranian EFL Learners' L2 Writing Anxiety and Attitudes. Journal of Applied Linguistics and Language Research, 4(2), $203-215$. 
Harris, K. R., Graham, S., \& Mason, L. H. (2006). Improving the Writing, Knowledge, and Motivation of Struggling Young Writers: Effects of Self-Regulated Strategy Development with and without Peer Support. American Educational Research Journal, 43(2), 295-340.

Huang, H. Y. (2006). Chaoyang University of Technology Students' Attitude and Motivation toward Native Language and Foreign Language as a Medium of Instruction in English Writing Class. Unpublished Master's Thesis, Chaoyang University of Technology, Taiwan.

Hussin, S., Abdullah, M. Y., Ismail, N., \& Yoke, S. K. (2015). The Effects of CMC Applications on ESL Writing Anxiety among Postgraduate Students. English Language Teaching, 8(9), 167 $-172$.

Ismail, S., \& Maasum, T. M. N. R. (2009). The Effects of Cooperative Learning in Enhancing Writing Performance. SOLLS.INTEC 09 International Conference, $400-434$.

Jawas, U. (2019). Writing Anxiety among Indonesian EFL Students: Factors and Strategies. International Journal of Instruction, 12(4), 733 - 746.

Jebreil, N., Azizifar, A., \& Gowhary, H. (2015). Investigating the Effect of Anxiety of Male and Female Iranian EFL Learners on their Writing Performance. 3rd World Conference on Psychology and Sociology (WCPS). Procedia - Social and Behavioral Sciences, 185, 190 196.

Keshavarz, S. M., Shahrokhi, M., \& Talebi-Nejad, M. R. (2014). The Effect of Cooperative Learning Techniques on Promoting Writing Skill of Iranian EFL Learners. International Journal of Language Learning and Applied Linguistics World, 5(1), 78 - 90.

Keskin, S., \& Yurdugul, H. (2019). Factors Affecting Students' Preferences for Online and Blended Learning: Motivational VS. Cognitive. European Journal of Open, Distance and e-Learning, 22(2), $72-86$.

Kurniasih, Sholihah, F. A., Umamah, A., \& Sung, I. H. (2020). Writing Process Approach and Its Effect on Students' Writing Anxiety and Performance. Jurnal Arbitrer, 7(2), 144- 150.

Liao, M. T., \& Wong, C. T. (2007). Effects of Dialogue Journals on L2 Students' Writing Fluency, Reflections, Anxiety, and Motivation. Reflections on English Language Teaching, 9(2), $139-170$.

Lin, G. H. C., \& Ho, M. M. S. (2009). An Exploration into Foreign Language Writing Anxiety from Taiwanese University Students' Perspectives. Proceedings of 2009 NCUE Fourth Annual Conference on Language, Teaching, Literature, Linguistics, Translations and Interpretation, 307 - 318.

Liu, Y. (2020). The Effect of Sentence-Making Practice on Adult EFL Learners' Writing Anxiety A Comparative Study. English Language Teaching, 13(6), $34-47$.

Martinez, C. T., Kock, N., \& Cass, J. (2011). Pain and Pleasure in Short Essay Writing: Factors Predicting University Students' Writing Anxiety and Writing Self-Efficacy. Journal of Adolescent \& Adult Literacy, 54(5), $351-360$.

Masriani, E., Mukhaiyar \& Wahyuni, D. (2018). Writing Anxiety and Writing Strategies Used by English Department Students of Universitas Negeri Padang. Lingua Didaktika, 12(1), $76-85$.

Mat Daud, N. S., Mat Daud, N., \& Abu Kassim, N. L. (2005). Second Language Writing Anxiety: Cause or Effect? Malaysian Journal of ELT Research, 1(1), $1-19$. Retrieved $2^{\text {nd }}$ January 2021 from http://journals.melta.org.my/index.php/majer/article/view/189/101

Miri, M. A., \& Joia, J. (2018). Writing Anxiety in an Afghan EFL Setting: Voices From Five Afghan Students. Journal of Foreign Language Teaching \& Learning, 3(1), $14-29$.

Kassem, M. A. (2017). Developing Business Writing Skills and Reducing Writing Anxiety of EFL Learners through Wikis. English Language Teaching, 10(3), 151- 163. 
Nazari, M., Farnia, M., Ghonsooly, B., \& Jafarigohar, M. (2019). Contradictions in Writing Anxiety: A Qualitative Case Study of Expansive Learning among Iranian EFL Learners. Journal of Language and Translation, 9(1), $33-49$.

Picciano, A. G. (2012). The evolution of big data and learning analytics in American higher education. Journal of Asynchronous Learning Networks, 16 (3), 9 - 20.

Qashoa, S. H. H. (2014). English writing anxiety: alleviating strategies. LINELT 2013. ProcediaSocial and Behavioral Sciences, 136, $59-65$.

Rabadi, R. I., \& Rabadi, A. D. (2020). Do Medical Students Experience Writing Anxiety While Learning English as a Foreign Language? Psychology Research and Behavior Management, 13, 883-893. Retrieved $2^{\text {nd }}$ January 2021 from https://www.ncbi.nlm.nih.gov/pmc/articles/PMC7610028/

Rezaei, M., \& Jafari, M. (2014). Investigating the Levels, Types, and Causes of Writing Anxiety among Iranian EFL Students: A Mixed Method Design. International Conference on Current Trends in ELT. Procedia - Social and Behavioral Sciences, 98, 1545 - 1554.

Sabti, A. A., Md Rashid, S., Nimehchisalem, V., \& Darmi, R. (2019). The Impact of Writing Anxiety, Writing Achievement Motivation, and Writing Self-Efficacy on Writing Performance: A Correlational Study of Iraqi Tertiary EFL Learners. Sage Open, 1 - 13.

Saedpanah, E., \& Mahmoodi, M. H. (2020). Critical Thinking, Writing Strategy Use, L2 Writing Anxiety and L2 Writing Performance: What are the relations? Journal of English language, 12(25), $240-267$.

Sivaci, S. (2020). The Effects of Peer Feedback on Writing Anxiety Levels of Pre-Service English Teachers. The Reading Matrix: An International Online Journal, 20(2), 131 - 139.

Soleimani, H., Hamasaid, H. H., \& Saheb, B. M. (2020). L2 Writing Anxiety, Writing Self efficacy and Writing Motivation as Correlates of Global L2 Writing Performance. Koya University Journal of Humanities and Social Sciences, 3(1), $156-165$.

Syarifudin. (2020). Survey on EFL Students' Writing Anxiety: Level, Types, and Causes. Eralingua: Jurnal Pendidikan Bahasa Asing dan Sastra, 4(2), 122 - 132.

Teksan, K. (2013). Analysis of writing anxiety of secondary school students according to several variables. African Journal of Agricultural Education, 1(4), $062-067$.

Thevasigamoney, A. F., \& Md. Yunus, M. (2014). A glimpse into E-Mail Dialogue Journal Writing (EDJW) and writing anxiety among gifted learners. TTLC 2013. Procedia - Social and Behavioral Sciences, 123, $266-271$.

Tsiriotakis, I. K., Vassilaki, E., Spantidakis, I., \& Stavrou, N. A. M. (2017). The Examination of the Effects of Writing Strategy-Based Procedural Facilitative Environments on Students' English Foreign Language Writing Anxiety Levels. Frontiers in Psychology, 7, 1- 14.

Türnük, T., \& Aydin, S. (2020). Interlanguage effect on writing anxiety in a foreign language context. The Literacy Trek, 6(1), $1-19$.

Vieira, I., Lopes, A. P., \& Suares, F. (2014). The Potential Benefits Of Using Videos In Higher Education. Proceedings of EDULEARN14 Conference $7^{\text {th }}-9^{\text {th }}$ July 2014, Barcelona, Spain. $0750-0756$.

Vonderwell, S., \& Zachariah, S. (2005). Factors that Influence Participation in Online Learning. Journal of Research on Technology in Education, 38(2), 213 - 230.

$\mathrm{Wu}, \mathrm{H}$. J. (2015). The Effects of Blog-supported Collaborative Writing on Writing Performance, Writing Anxiety and Perceptions of EFL College Students in Taiwan. Doctoral dissertation, University of South Florida. Retrieved from https://scholarcommons.usf.edu/etd/5600/ 
Yavuz, F., Ozdemir, E., \& Celik, O. (2020). The Effect of Online Gamification On EFL Learners' Writing Anxiety Levels: A Process-Based Approach. World Journal on Educational Technology: Current Issues, 12(2), $62-70$.

Yu, S., Zhou, N., Zheng, Y., Zhang, L., Cao, H., \& Li, X. (2019). Evaluating student motivation and engagement in the Chinese EFL writing context. Studies in Educational Evaluation, $62,129-141$.

Zhang, H. (2011). Language Anxiety in ESL classroom: Analysis of Turn-taking patterns in ESL Classroom Discourse. Proceedings of 2011 International Conference on Education, Research and Innovation.

Zhang, X. (2019). Exploring the relationship between college students' writing anxiety and the pedagogical use of online resources. International Journal of Educational Technology in Higher Education, 1- 18. 